\title{
Propionate precursors and other metabolic intermediates as possible alternative electron acceptors to methanogenesis in ruminal fermentation in vitro
}

\author{
C. J. Newbold ${ }^{1 *}$, S. López ${ }^{2}$, N. Nelson ${ }^{3}$, J. O. Ouda ${ }^{4}$, R. J. Wallace ${ }^{3}$ and A. R. Moss ${ }^{4}$ \\ ${ }^{1}$ Institute of Rural Sciences, University of Wales, Aberystwyth SY23 3AL, UK \\ ${ }^{2}$ Department of Animal Production, University of León, E-24071 León, Spain \\ ${ }^{3}$ Rowett Research Institute, Bucksburn, Aberdeen AB21 9SB, UK \\ ${ }^{4}$ ADAS Feed Evaluation and Nutritional Sciences, Alcester Road, Stratford-upon-Avon CV37 9RQ, UK \\ (Received 1 July 2004 - Revised 25 January 2005 - Accepted 31 January 2005)
}

\begin{abstract}
Fifteen potential precursors of propionate were tested for their ability to decrease $\mathrm{CH}_{4}$ production by ruminal fluid in vitro. Sodium acrylate and sodium fumarate produced the most consistent effects in batch cultures, with $50 \%$ of the added precursors being fermented to propionate and $\mathrm{CH}_{4}$ production decreasing by between 8 and $17 \%$, respectively. Additives were more effective when added as free acids, but this also decreased the $\mathrm{pH}$ and may have inhibited fibre digestion. Changing the dietary substrate from predominantly grass hay to predominantly concentrate had no influence on the effectiveness of acrylate and fumarate. In an in vitro fermentor (the rumen simulating technique, Rusitec) with a grass hay—concentrate (50:50, w/w) diet as substrate, both compounds were again fermented to propionate (33 and $44 \%$ conversion to propionate, respectively). However, fumarate appeared more effective as a $\mathrm{H}_{2}$ sink compound. It was calculated to capture $44 \%$ of the $\mathrm{H}_{2}$ previously used for $\mathrm{CH}_{4}$ formation compared with a $22 \%$ capture of $\mathrm{H}_{2}$ with acrylate. Fumarate also caused a stimulation in fibre digestion. Thus, sodium fumarate was the preferred propionate precursor for use as a feed ingredient to decrease $\mathrm{CH}_{4}$ emissions from ruminants.
\end{abstract}

Methane: Fumarate: Rumen: Organic acids

Reducing equivalents generated during ruminal fermentation are disposed of partly by the formation of $\mathrm{CH}_{4}$, which is energetically wasteful and environmentally damaging. Many chemical compounds have been tested as potential feed additives for ruminants on the basis of their direct or indirect effects on $\mathrm{CH}_{4}$ production in the rumen (Moss, 1993; Van Nevel \& Demeyer, 1996; Demeyer \& Fievez, 2000). These compounds include ionophores, halogenated $\mathrm{CH}_{4}$ analogues and unsaturated fatty acids (Van Nevel \& Demeyer, 1996; Demeyer \& Fievez, 2000). Different biotechnological approaches have been investigated that might induce changes in the ruminal microbial population, such as defaunation (Newbold et al. 1995), which decreases the number of protozoaassociated methanogenic archaea, or the enhancement of acetogenesis in the rumen (López et al. 1999a).

Another means of diverting $\mathrm{H}_{2}$ away from $\mathrm{CH}_{4}$ formation would be to promote alternative electron-sink metabolic pathways to dispose of the reducing power (López et al. 1999b; Ungerfeld et al. 2003a). Both fumarate and malate are key intermediates in the succinate-propionate pathway, in which malate is dehydrated to fumarate and fumarate reduced to succinate, which is then decarboxylated to propionate (Fig. 1). Reducing equivalents are consumed in the reduction of fumarate to succinate, and hence both fumarate and malate have been shown to compete successfully for $\mathrm{H}_{2}$ in the rumen, with subsequent decreases in methanogenesis both in vitro and in vivo (Asanuma et al. 1999; López et al. 1999b; Bayaru et al. 2001; Jalc \& Ceresnakova, 2002; Carro \& Ranilla, 2003a,b). However, the diversion of $\mathrm{H}_{2}$ to propionate was incomplete and may have been affected by the propionate precursor used, the quantity added or the basal diet (Callaway \& Martin, 1996; Carro \& Ranilla, 2003a,b).

The present study was undertaken to explore a range of precursors of propionate, either as free acids or as salts, as possible feed additives that would divert metabolic $\mathrm{H}_{2}$ away from $\mathrm{CH}_{4}$ to more useful products. Short-term in vitro batch incubations were used to evaluate whether the efficacy of the additives was affected by the forage:concentrate ratio of the diet. The long-term effects of promising candidates were then further evaluated in the rumensimulating fermentor (Rusitec).

\section{Materials and methods}

Experiment 1: Influence of adding propionate precursors as sodium salts or free acids

Fourteen compounds were tested, all of which were propionate precursors or metabolic intermediates in the different pathways of 


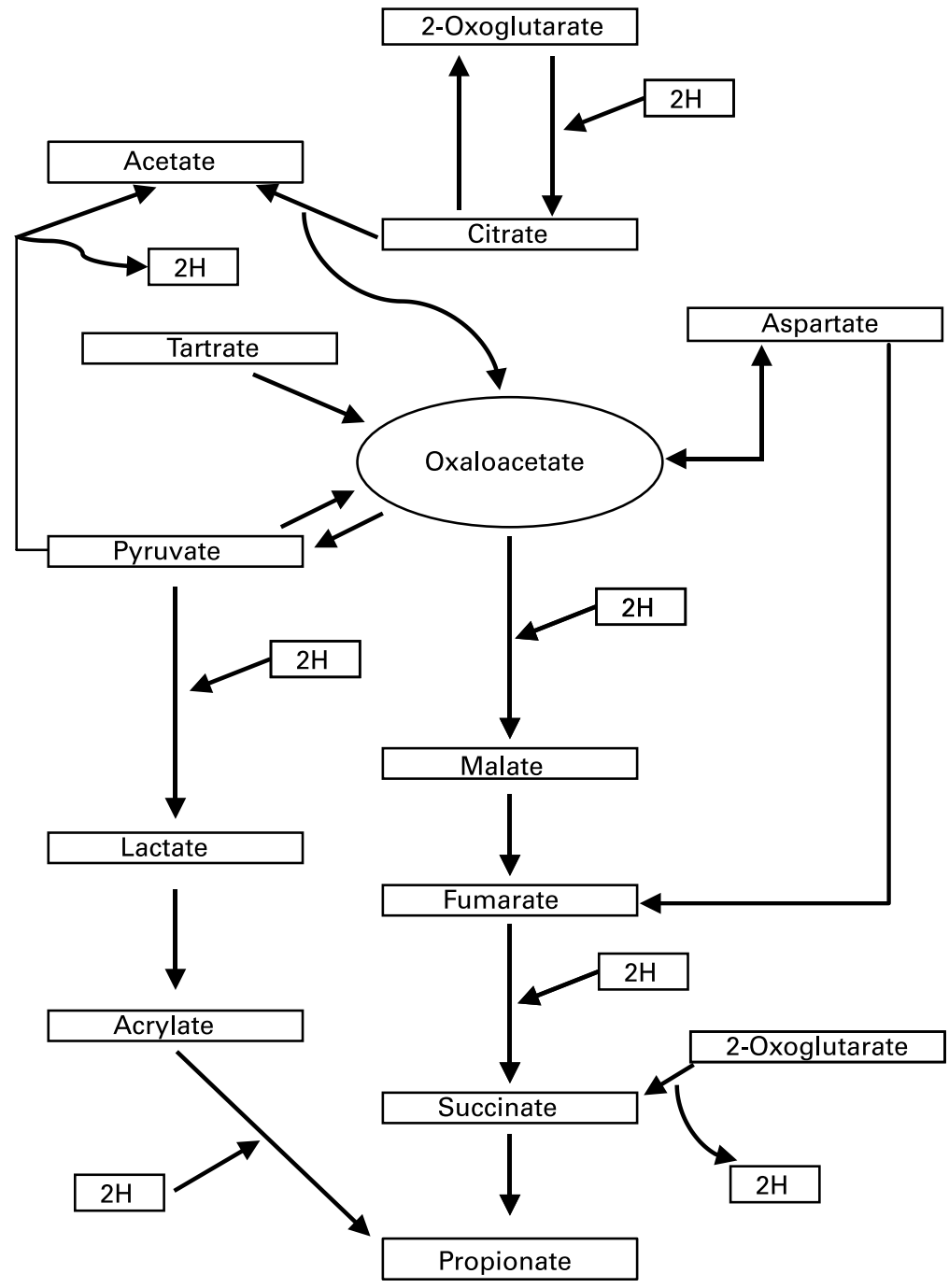

Fig. 1. Possible fermentation pathways for selected propionate precursors in the rumen.

volatile fatty acid (VFA) synthesis during ruminal fermentation (Fig. 1). Propionate itself was included as a control. The compounds used as additives were: pyruvate (sodium salt; Sigma Chemical Co., St Louis, MO, USA), L-lactate (sodium salt; Fluka Chemie, Buchs ZH, Switzerland), acrylate (sodium salt; Aldrich Chemical Co., St Louis, MO, USA), DL-aspartate (potassium salt; Fluka Chemie), fumarate (disodium salt; Sigma Chemical Co.), DL-malate (disodium salt; Aldrich Chemical Co.), citrate (trisodium salt; Sigma Chemical Co.), 2-oxoglutarate ( $\alpha$-ketoglutaric acid disodium salt; Sigma Chemical Co.), L (+)-tartrate (disodium salt dihydrate; Sigma Chemical Co.) and propionate (sodium salt; Sigma Chemical Co.). To test whether the form (salt or acid) of the compound added had any influence on the effect of the additive, the following acids were also used: DL-aspartic acid (Fluka Chemie), fumaric acid (Sigma Chemical Co.), DL-malic acid (Fluka Chemie) and citric acid (Sigma Chemical Co.).

In vitro incubations were carried out with ruminal fluid obtained $2 \mathrm{~h}$ after the morning feeding, from three rumen-cannulated sheep fed $1 \mathrm{~kg} / \mathrm{d}$ of a good-quality grass hay. Ruminal contents were mixed and strained through two layers of muslin and maintained at $39^{\circ} \mathrm{C}$ under $\mathrm{O}_{2}$-free $\mathrm{CO}_{2}$. Ruminal fluid was diluted anaerobically into the medium described by Goering \& Van Soest
(1970) containing (per litre): $475 \mathrm{ml}$ distilled water, $1.25 \mathrm{ml}$ trace elements solution $\left(13.2 \mathrm{~g} \mathrm{CaCl} 2 \cdot 2 \mathrm{H}_{2} \mathrm{O}, 10 \mathrm{~g} \mathrm{MnCl}_{2} \cdot 4 \mathrm{H}_{2} \mathrm{O}, 1 \mathrm{~g}\right.$ $\mathrm{CoCl}_{2} \cdot 6 \mathrm{H}_{2} \mathrm{O}$ and $0.8 \mathrm{~g} \mathrm{FeCl}_{2} \cdot 6 \mathrm{H}_{2} \mathrm{O}$ per litre), $237.5 \mathrm{ml}$ buffer solution $\left(35 \mathrm{~g} \mathrm{NaHCO}_{3}\right.$ and $4 \mathrm{~g}\left(\mathrm{NH}_{4}\right) \mathrm{HCO}_{3}$ per litre), $237.5 \mathrm{ml}$ macromineral solution $\left(5.7 \mathrm{~g} \mathrm{Na}_{2} \mathrm{HPO}_{4}, 6.2 \mathrm{~g} \mathrm{KH}_{2} \mathrm{PO}_{4}\right.$ and $0.6 \mathrm{~g}$ $\mathrm{MgSO}_{4} .7 \mathrm{H}_{2} \mathrm{O}$ per litre), $1.25 \mathrm{ml}$ resazurin solution $(1 \mathrm{~g} / \mathrm{L})$ and $47.5 \mathrm{ml}$ freshly prepared reducing solution $(6.25 \mathrm{~g}$ cysteine hydrochloride, $40 \mathrm{ml} 1 \mathrm{M}-\mathrm{NaOH}$ and $6.25 \mathrm{~g} \mathrm{Na}_{2} \mathrm{~S} .9 \mathrm{H}_{2} \mathrm{O}$ per litre). After mixing, $50 \mathrm{ml}$ buffered ruminal fluid were dispensed anaerobically to $120 \mathrm{ml}$ serum bottles containing $400 \mathrm{mg}$ diet $\mathrm{F}$ (Table 1), containing $750 \mathrm{~g} / \mathrm{kg}$ forage and $250 \mathrm{~g} / \mathrm{kg}$ concentrate, previously ground to pass through a $1 \mathrm{~mm}$ mesh screen. Solutions $(0.4 \mathrm{M})$ of the different additives used in each experiment were prepared in distilled water, and $1 \mathrm{ml}$ of each solution $(400 \mu \mathrm{mol}$ additive) was added to each of two incubation bottles, to achieve final concentrations of $8 \mathrm{~mm}$. Another two bottles received $1 \mathrm{ml}$ distilled water (control cultures).

The bottles were sealed under a $\mathrm{CO}_{2}$ atmosphere with rubber stoppers and aluminium caps, and were incubated at $39^{\circ} \mathrm{C}$. Incubations were performed on $3 \mathrm{~d}$ with two replicates per day, and a total of thirty bottles (fourteen additives plus control, with two replicates each) was incubated in each run. After $24 \mathrm{~h}$ 
Table 1. Ingredients and chemical composition of diets used as substrates in in vitro incubations

\begin{tabular}{lccc}
\hline & General-purpose diet & High-forage diet & High-concentrate diet \\
\hline Ingredients (g/kg DM) & & & \\
$\quad$ Grass hay & 500 & 750 & 210 \\
$\quad$ Alfalfa hay & & 80 & 320 \\
Maize & $299 \cdot 4$ & 70 & 280 \\
Barley & & 30 & 120 \\
Soyabean meal & 91 & & \\
Fish meal & 100 & 30 & 30 \\
Molasses & 9.5 & 40 & 40 \\
$\quad$ Vitamin-mineral mixture & & & \\
Chemical composition (g/kg DM) & 832 & 856 & 162 \\
$\quad$ Organic matter & 148 & 175 & 187 \\
Crude protein & 515 & 326 & 81 \\
Neutral detergent fibre & 244 & 204 & 4 \\
Acid detergent fibre & ND & 31 & \\
$\quad$ Acid detergent lignin & & &
\end{tabular}

ND, not determined.

incubation, fermentation was arrested by chilling to $4^{\circ} \mathrm{C}$, and the quantities of fermentation products (total gas, $\mathrm{CH}_{4}$ and VFA) formed were determined in each bottle following the methods of analysis described below.

Total gas was measured using a $100 \mathrm{ml}$ lubricated syringe connected to a needle, which was injected through the stoppers into the headspace. A gas sample $(1 \mathrm{ml})$ was removed from each bottle and analysed for $\mathrm{CH}_{4}$ and $\mathrm{H}_{2}$ by GLC as described by López et al. (1999b), using PYE 4500 Unicam GC containing a $4 \mathrm{~mm} \times 3 \mathrm{~m}$ glass column packed with Porapak Q mesh 60-80 (Waters Associates Inc., Milford, MA, USA). The oven temperature was $65^{\circ} \mathrm{C}$ and the carrier gas (He) flow rate was $30 \mathrm{ml} / \mathrm{min}$; a katherometer detector was used. Peaks were identified by comparison with gas standards of known composition.

The bottles were then uncapped and (only in Expt 1) the $\mathrm{pH}$ measured using a $\mathrm{pH}$ meter. Fermentation fluid $(1 \mathrm{ml})$ was added to $0.2 \mathrm{ml}$ of an acid solution containing $200 \mathrm{~g} / \mathrm{l}$ orthophosphoric acid and $20 \mathrm{~mm} 2$-ethyl-butyric acid. Acidified samples were centrifuged $\left(27800 \mathrm{~g}, 5^{\circ} \mathrm{C}, 15 \mathrm{~min}\right)$, and VFA were determined by GLC using ethyl-butyric acid as the internal standard, as described by Stewart and Duncan (1985). In Expt 1 only, DM disappearance (apparent DM degradation) was measured by filtering all the bottle contents using previously tared $50 \mathrm{ml}, 40 \mathrm{~mm}$ plate, coarseporosity, fritted-glass crucibles under a moderate vacuum.

The number of replicates for each experimental treatment was six (three experimental days with duplicated observations each day). To assess the differences between additives, one-way ANOVA was performed on data from the investigation into adding propionate precursors as sodium salts on in vitro fermentation, with additive as the treatment factor (ten additives plus control) and experimental day as a blocking factor and Quercus Suber L., considered. The statistical model used was:

$$
y_{\mathrm{ijkl}}=\mu+A_{\mathrm{i}}+D_{\mathrm{j}}+\varepsilon_{\mathrm{ijk}}
$$

where $y_{\mathrm{ijk}}$ is the value for each observation, $\mu$ is the overall mean, $A_{\mathrm{i}}$ represents the ith treatment effect (additive), $D_{\mathrm{j}}$ is the effect of the jth block (day) and $\varepsilon_{\mathrm{ijk}}$ is the random error.

Propionate addition was considered as a 'positive' control, representing the case in which an equimolar amount of the end-product is directly added to the medium. Dunnett's test was performed to determine whether any treatments were significantly different from either the control (no acid) or the propionate treatment. To evaluate differences between the addition of the acid or its corresponding salt, ANOVA was performed using a nested design with additive and form of presentation (acid or salt) within each additive as the treatment factors. In this case, the statistical model used was:

$$
y_{\mathrm{ijkl}}=\mu+A_{\mathrm{i}}+S_{\mathrm{j}(\mathrm{i})}+D_{\mathrm{k}}+\varepsilon_{\mathrm{kl}(\mathrm{ij})}
$$

where $y_{\mathrm{ijk}}$ is the value for each observation, $\mu$ is the overall mean, $A_{\mathrm{i}}$ represents the ith treatment effect (additive), $S_{\mathrm{j}(\mathrm{i})}$ is the effect of the jth level of factor $S$ (additive form, salt or acid) within each ith level of factor $A, D_{\mathrm{k}}$ is the effect of the kth block (day) and $\varepsilon_{\mathrm{kl}(\mathrm{ij})}$ is the random error.

\section{Experiment 2: Influence of diet on effectiveness of additives}

The effects of adding propionate precursors on in vitro fermentation were compared with forage or concentrate diets as substrate. The compounds used as additives in this case were acrylate (sodium salt), DL-aspartate (potassium salt), fumarate (disodium salt), DL-malate (disodium salt), 2-oxoglutarate ( $\alpha$-ketoglutaric acid disodium salt), oxaloacetate (free acid) and propionate (sodium salt).

The donor sheep in this experiment received a mixed diet $(1.4 \mathrm{~kg} / \mathrm{d})$ consisting of grass hay, barley, molasses, white fishmeal and a vitamin and mineral mixture (general-purpose diet, Table 1) in two equal meals. The two diets ( $\mathrm{F}$ and $\mathrm{C}$ ) described in Table 1 were used as substrates for in vitro incubation, so the total number of bottles incubated in each run was thirty-two (seven additives plus control in each of two diets, with two replicates each), and incubations were again performed on three nonconsecutive days. The fermentation parameters measured in each bottle after $24 \mathrm{~h}$ incubation were total gas and $\mathrm{CH}_{4}$ production, and VFA concentrations.

Data from the study investigating the effect of adding propionate precursors on the in vitro fermentation of forage or concentrate diets were analysed by two-way ANOVA according to a factorial design with diet and additive (seven additives plus control) as main factors of variation, and with experimental day as a blocking factor. In this case, the statistical model used was:

$$
y_{\mathrm{ijkl}}=\mu+A_{\mathrm{i}}+F_{\mathrm{j}}+A F_{(\mathrm{ij})}+D_{\mathrm{k}}+\varepsilon_{\mathrm{ijkl}}
$$


where $y_{\mathrm{ijk}}$ is the value for each observation, $\mu$ is the overall mean, $A_{\mathrm{i}}$ represents the effect of ith level of factor $A$ (additive), $F_{\mathrm{j}}$ is the effect of the jth level of factor $F$ (feed), $A F_{(\mathrm{ij})}$ is the effect of the interaction $A \times F, D_{\mathrm{k}}$ is the effect of the kth block (day) and $\varepsilon_{\mathrm{kl}(\mathrm{ij})}$ is the random error. A one-way ANOVA to study the effects of the additive used was then performed for each diet separately. The model was then $y_{\mathrm{ijk}}=\mu+A_{\mathrm{i}}+D_{\mathrm{j}}+\varepsilon_{\mathrm{ijk}}$, as explained above.

\section{Experiment 3: Influence of fumarate and acrylate on fermentation in Rusitec}

The rumen simulation technique (Rusitec) was used as described by Czerkawski \& Breckenridge (1977). Twelve vessels were supplied at the same time every day with $20 \mathrm{~g}$ basal diet fed to the donor animals. The duration of the experiment was $21 \mathrm{~d}$, during which four vessels received $6.25 \mathrm{mmol} / \mathrm{d}$ fumarate (disodium salt)/d, four vessels received $6.25 \mathrm{mmol} / \mathrm{d}$ acrylate (sodium salt) added to the basal diet, and the remaining vessels were controls. The nominal volume in each reaction vessel was $850 \mathrm{ml}$, and the dilution rate was set at $0 \cdot 88 / \mathrm{d}$, the infused liquid being artificial saliva (McDougall, 1948) at $\mathrm{pH} 8$.4. Inocula for the fermentation vessels were obtained from a pooled sample (liquid and particulate rumen contents) from three ruminally cannulated sheep fed $1.4 \mathrm{~kg} / \mathrm{d}$ general-purpose diet (Table 1) in two equal meals.

On the first day of the experiment, $300 \mathrm{ml}$ strained ruminal fluid and $300 \mathrm{ml}$ artificial saliva were transferred to each reaction vessel. Solid ruminal contents $(80 \mathrm{~g})$ were weighed into a nylon bag that was placed inside the food container in each vessel together with a bag of food. The food was the same diet (general-purpose diet; Table 1) fed to the donor animals and was provided in nylon bags, pore size $50 \mu \mathrm{m}$, which were gently agitated in the liquid phase. Two bags were present at any time, and one bag was replaced each day to give a $48 \mathrm{~h}$ incubation. The bags that were removed from the vessels were placed in plastic bags, and their contents were washed and squeezed with $40 \mathrm{ml}$ artificial saliva. This was done twice for each bag, the combined washings being poured back into the reaction vessels. Fermentation vessels were flushed with anaerobic grade $\mathrm{CO}_{2}$ before filling, after filling and then every day during feeding (when the nylon bags with the food were changed).

Gas samples were taken over days 10 to 19 and analysed for $\mathrm{CH}_{4}$ and $\mathrm{H}_{2}$ by GLC as described above. During the last $2 \mathrm{~d}$ of the experiment, fermentation products were determined on samples taken from the liquid overflow, as described by Newbold et al. (1997). Fermentation acids were detected by GLC as described above. Ammonia was measured by the phenol-hypochlorite method of Weatherburn (1967). The volume of the liquid overflow, together with the concentration of fermentation products, was used to calculate the daily output of individual VFA and ammonia. $\mathrm{pH}$ was measured as described above in samples of fermentation fluid withdrawn from around the nylon bags at the time of feeding. The apparent degradation of the diet was estimated from the DM remaining in the bags after $48 \mathrm{~h}$ incubation. DM in feed samples and in incubation residues was determined by drying at $105^{\circ} \mathrm{C}$ for $48 \mathrm{~h}$.

Samples for microbial counts were also taken on the last $2 \mathrm{~d}$ of the period. Protozoa in the liquid phase were enumerated microscopically in a counting chamber (Newbold et al. 1987). Hungate's methods (Hungate, 1969) were used to prepare media and to cultivate bacteria. Media were dispensed into Hungate tubes sealed with butyl rubber stoppers (Bellco Glass Inc., Vineland, NJ, USA). A sample of fermentation fluid $(20 \mathrm{ml})$ taken directly from the reaction vessel together with a sample of the digesta $(1 \mathrm{~g})$ remaining in the nylon bags incubated for the last $48 \mathrm{~h}$ were homogenized, under $\mathrm{O}_{2}$-free $\mathrm{CO}_{2}$, for $1 \mathrm{~min}$ using an MSE top-bladed homogenizer Machine Shop Equipment Ltd, Crawley, Surrey at full speed. Serial ten-fold dilutions were prepared under $\mathrm{O}_{2}$-free $\mathrm{CO}_{2}$ for each sample by the anaerobic method of Bryant (1972) using an anaerobic diluent (Mann, 1968). Total viable bacteria were enumerated in roll tubes with a complex rumen fluid plus sugars medium to which $20 \mathrm{~g} / \mathrm{l}$ agar was added (medium M2; Hobson, 1969), and these tubes were incubated for $72 \mathrm{~h}$ at $39^{\circ} \mathrm{C}$. Cellulolytic bacterial counts were made by a most-probable-number method based on the degradation of filter paper strips (Mann, 1968).

Results were analysed by one-way ANOVA. Each vessel was considered as an experimental unit, with the acid added (control, fumarate or acrylate) as the treatment factor. Again, the model used was $y_{\mathrm{ijk}}=\mu+A_{\mathrm{i}}+D_{\mathrm{j}}+\varepsilon_{\mathrm{ijk}}$, as explained above. Following a significant $F$ test $(P<0 \cdot 05)$, differences among means were examined by the least significant difference test (Steel \& Torrie, 1980).

\section{Results}

Effects of adding propionate precursors as sodium salts or free acids on in vitro fermentation (Experiment 1)

Ten sodium salts (Table 2) and five free acids (Table 3) were tested for their influence on fermentation in Expt 1. Propionate concentrations increased most with sodium acrylate $(+52 \%)$, sodium fumarate $(+59 \%)$ and sodium malate $(+51 \%)$. Sodium citrate produced abundant acetate, but propionate and butyrate production were small, and there was no significant inhibition of $\mathrm{CH}_{4}$ formation. The greatest inhibition of $\mathrm{CH}_{4}$ formation with the sodium salts occurred with acrylate $(-14 \%)$ and fumarate $(-9 \%)$. 2-Oxoglutarate also caused a significant decrease in $\mathrm{CH}_{4}(-13 \%)$, in spite of a relatively small increase in propionate concentration. Acetate and butyrate were the main products formed from 2-oxoglutarate. Butyrate, together with acetate and propionate, was also formed from sodium lactate, but no decrease in $\mathrm{CH}_{4}$ formation was observed. Aspartic, fumaric and malic acids produced propionate, fumaric acid giving the greatest decrease in $\mathrm{CH}_{4}$ formation (Table 3 ). $\mathrm{CH}_{4}$ production was inhibited more when fumarate was added as a free acid $(-17 \%)$ rather than a sodium salt $(-8 \%)$. Supplementation with the sodium salts of fumarate, 2-oxoglutarate, lactate, malate, pyruvate and tartrate stimulated apparent DM degradation by between 10 and $16 \%$, and no stimulation was observed when the free acids were added.

Only sodium pyruvate, malic and tartaric acids significantly decreased $\mathrm{pH}$. Even when statistically significant, however, the effect was very small, all changes being a difference of $0 \cdot 11$ units or less, and the lowest $\mathrm{pH}$ recorded was 6.49. The calculated $\mathrm{H}_{2}$ recovery was usually $80 \%$ or above, with the exceptions of sodium citrate, citric acid and 2-oxoglutarate, which gave about $70 \%$ recovery.

Effects of adding propionate precursors on in vitro fermentation of high-forage or high-concentrate diets (Experiment 2)

Sodium fumarate and sodium acrylate caused significant decreases in $\mathrm{CH}_{4}$ production and increases in propionate 
Table 2. The effects of adding propionate precursors as sodium salts on DM degradation and ruminal fermentation in vitro

\begin{tabular}{|c|c|c|c|c|c|c|c|c|c|}
\hline & $\begin{array}{c}\text { DM degradation } \\
(\mathrm{g} / \mathrm{kg})\end{array}$ & $\mathrm{pH}$ & $\begin{array}{l}\text { Gas } \\
(\mathrm{ml} / \mathrm{d})\end{array}$ & $\begin{array}{c}\mathrm{CH}_{4} \\
(\mu \mathrm{mol} / \mathrm{d})\end{array}$ & $\begin{array}{l}\text { Acetate } \\
(\mu \mathrm{mol} / \mathrm{d})\end{array}$ & $\begin{array}{c}\text { Propionate } \\
(\mu \mathrm{mol} / \mathrm{d})\end{array}$ & $\begin{array}{l}\text { Butyrate } \\
(\mu \mathrm{mol} / \mathrm{d})\end{array}$ & $\begin{array}{c}\text { VFA } \\
(\mu \mathrm{mol} / \mathrm{d})\end{array}$ & $\begin{array}{c}\mathrm{H}_{2} \text { recovery } \\
(\%)\end{array}$ \\
\hline No addition & 571 & $6 \cdot 60$ & $72 \cdot 8$ & 636 & 1420 & 458 & 187 & 2131 & 95.0 \\
\hline Aspartate & 607 & 6.56 & $76 \cdot 5^{a, b}$ & 596 & $1556^{\mathrm{a}}$ & $666^{a, b}$ & 205 & $2496^{a}$ & 89.9 \\
\hline Citrate & 627 & 6.58 & $80 \cdot 7^{a, b}$ & 614 & $2162^{a, b}$ & $495^{\mathrm{b}}$ & 206 & $2933^{a, b}$ & $68 \cdot 4$ \\
\hline Fumarate & $640^{\mathrm{a}}$ & 6.59 & $75 \cdot 9^{a, b}$ & $582^{b}$ & 1515 & $730^{a, b}$ & 198 & $2513^{\mathrm{a}}$ & 91.9 \\
\hline 2-Oxoglutarate & $662^{a}$ & 6.56 & $75 \cdot 0$ & $552^{a, b}$ & $1841^{a, b}$ & $505^{\mathrm{b}}$ & $242^{a, b}$ & $2656^{a}$ & $72 \cdot 0$ \\
\hline Malate & $638^{a}$ & $6 \cdot 61$ & $77 \cdot 8^{a, b}$ & 613 & $1600^{a, b}$ & $693^{a, b}$ & $227^{a, b}$ & $2591^{a}$ & 89.5 \\
\hline Pyruvate & $657^{a}$ & $6 \cdot 54^{a}$ & $79 \cdot 0^{a, b}$ & $586^{\mathrm{b}}$ & $1643^{a, b}$ & $506^{b}$ & 202 & $2417^{\mathrm{a}, \mathrm{b}}$ & 81.9 \\
\hline Tartrate & $629^{a}$ & 6.57 & $80 \cdot 2^{a, b}$ & 654 & $1769^{a, b}$ & $436^{\mathrm{b}}$ & $222^{a, b}$ & $2493^{a}$ & 81.0 \\
\hline Propionate & 612 & 6.58 & $72 \cdot 4$ & 663 & 1450 & $904^{a}$ & 194 & $2620^{a}$ & $106 \cdot 3$ \\
\hline SED & 22.9 & 0.018 & $1 \cdot 18$ & $23 \cdot 6$ & $41 \cdot 2$ & $28 \cdot 4$ & 7.8 & 67.0 & \\
\hline
\end{tabular}

VFA, volatile fatty acids.

a,bTreatment was significantly $(P<0.05)$ different from control and propionate treatments, respectively.

${ }^{*} \mathrm{H}_{2}$ recovery was calculated as described by Demeyer and Van Nevel (1975), in which $2 \mathrm{H}$ released $=2 \mathrm{~A}+\mathrm{P}+4 \mathrm{~B}$ and $2 \mathrm{H}$ accepted $=4 \mathrm{M}+2 \mathrm{P}+2 \mathrm{~B}$.

Table 3. The effects of adding propionate precursors as free acids on DM degradation and ruminal fermentation in vitro

\begin{tabular}{|c|c|c|c|c|c|c|c|c|c|}
\hline & $\begin{array}{l}\text { DM degradation } \\
(\mathrm{g} / \mathrm{kg})\end{array}$ & $\mathrm{pH}$ & $\begin{array}{l}\text { Gas } \\
(\mathrm{ml} / \mathrm{d})\end{array}$ & $\begin{array}{c}\mathrm{CH}_{4} \\
(\mu \mathrm{mol} / \mathrm{d})\end{array}$ & $\begin{array}{l}\text { Acetate } \\
(\mu \mathrm{mol} / \mathrm{d})\end{array}$ & $\begin{array}{l}\text { Propionate } \\
(\mu \mathrm{mol} / \mathrm{d})\end{array}$ & $\begin{array}{l}\text { Butyrate } \\
(\mu \mathrm{mol} / \mathrm{d})\end{array}$ & $\begin{array}{c}\text { VFA } \\
(\mu \mathrm{mol} / \mathrm{d})\end{array}$ & $\begin{array}{c}\mathrm{H}_{2} \text { recovery } \\
(\%)\end{array}$ \\
\hline No addition & 571 & $6 \cdot 60$ & $72 \cdot 8$ & 636 & 1420 & 458 & 187 & 2131 & $95 \cdot 0$ \\
\hline Citric acid & 603 & $6 \cdot 53^{c}$ & $86 \cdot 1^{\mathrm{a}, \mathrm{c}}$ & 618 & $2005^{a, c}$ & 457 & 194 & $2714^{\mathrm{a}, \mathrm{c}}$ & $72 \cdot 0$ \\
\hline Fumaric acid & $576^{c}$ & $6 \cdot 55^{c}$ & $75 \cdot 5$ & $526^{a, c}$ & 1452 & $656^{\mathrm{a}, \mathrm{c}}$ & 196 & $2368^{\mathrm{a}, \mathrm{c}}$ & $87 \cdot 8$ \\
\hline Malic acid & $575^{\mathrm{c}}$ & $6 \cdot 49^{\mathrm{a}, \mathrm{c}}$ & $77 \cdot 1^{\mathrm{a}}$ & $552^{\mathrm{a}, \mathrm{c}}$ & $1564^{\mathrm{a}}$ & $662^{\mathrm{a}}$ & $222^{\mathrm{a}}$ & $2509^{a}$ & $85 \cdot 3$ \\
\hline Tartaric acid & 608 & $6 \cdot 51^{\mathrm{a}, \mathrm{c}}$ & $84 \cdot 4^{\mathrm{a}, \mathrm{c}}$ & 630 & $1695^{a}$ & 435 & $218^{a}$ & $2409^{a}$ & $81 \cdot 4$ \\
\hline SED (acid $v$. salt) & $27 \cdot 0$ & 0.024 & 1.46 & $24 \cdot 6$ & $42 \cdot 3$ & $25 \cdot 8$ & $8 \cdot 9$ & $64 \cdot 7$ & \\
\hline SED (acid $v$. control) & $30 \cdot 0$ & 0.023 & 1.65 & $25 \cdot 2$ & $44 \cdot 1$ & $25 \cdot 9$ & $10 \cdot 5$ & $68 \cdot 2$ & \\
\hline
\end{tabular}

VFA, volatile fatty acids.

Treatment was significantly $(P<0.05)$ different from control.

'Significant difference $(P<0.05)$ between the response to sodium salts (see Table 2$)$ and the corresponding free acids (Table 3 ).

${ }^{*} \mathrm{H}_{2}$ recovery was calculated as described by Demeyer and Van Nevel (1975), in which $2 \mathrm{H}$ released $=2 \mathrm{~A}+\mathrm{P}+4 \mathrm{~B}$ and $2 \mathrm{H}$ accepted $=4 \mathrm{M}+2 \mathrm{P}+2 \mathrm{~B}$.

production in incubations with high-forage $(+42$ and $38 \%$; Table 4) and high-concentrate (+42 and $26 \%$; Table 5) diets. The inhibition of $\mathrm{CH}_{4}$ production was similar in the two diets for sodium fumarate $(-6 v .-9 \%$ high-forage $v$. high-concentrate diet) and sodium acrylate $(-8 v .-7 \%$, respectively). As before, sodium malate formed a considerable amount of propionate but had less of an effect on $\mathrm{CH}_{4}$ production than fumarate or acrylate. The accumulation of $\mathrm{H}_{2}$ was minimal with all treatments, and calculated $\mathrm{H}_{2}$ recoveries were high.

\section{Effects of fumarate and acrylate on fermentation in Rusitec (Experiment 3)}

The addition of acrylate and fumarate increased the production of propionate in Rusitec by 28 and $37 \%$ respectively (Table 6). Total VFA produced tended to be higher in the fumaratesupplemented vessels $(P=0.087) . \mathrm{CH}_{4}$ production decreased by $28 \%$ in fumarate-supplemented vessels $(P<0.05)$, and acrylate supplementation had no significant $(P>0.05)$ effect on $\mathrm{CH}_{4}$

Table 4. The effects of adding propionate precursors on in vitro fermentation with a high-forage diet

\begin{tabular}{|c|c|c|c|c|c|c|c|c|}
\hline & $\begin{array}{l}\text { Gas } \\
(\mathrm{ml} / \mathrm{d})\end{array}$ & $\begin{array}{c}\mathrm{CH}_{4} \\
(\mu \mathrm{mol} / \mathrm{d})\end{array}$ & $\begin{array}{c}\mathrm{H}_{2} \\
(\mu \mathrm{mol} / \mathrm{d})\end{array}$ & $\begin{array}{l}\text { Acetate } \\
(\mu \mathrm{mol} / \mathrm{d})\end{array}$ & $\begin{array}{c}\text { Propionate } \\
(\mu \mathrm{mol} / \mathrm{d})\end{array}$ & $\begin{array}{l}\text { Butyrate } \\
(\mu \mathrm{mol} / \mathrm{d})\end{array}$ & $\begin{array}{c}\text { VFA } \\
(\mu \mathrm{mol} / \mathrm{d})\end{array}$ & $\begin{array}{c}\mathrm{H}_{2} \text { recovery } \\
(\%)\end{array}$ \\
\hline No addition & $82 \cdot 9$ & 620 & 0.78 & 1430 & 552 & 263 & 2349 & $94 \cdot 2$ \\
\hline Acrylate & $80 \cdot 8$ & $569^{a, b}$ & 1.04 & 1534 & $760^{a, b}$ & $193^{a, b}$ & $2573^{a, b}$ & $92 \cdot 8$ \\
\hline Aspartate & $86 \cdot 2$ & 606 & 0.25 & 1458 & $665^{a, b}$ & 244 & $2475^{\mathrm{b}}$ & $95 \cdot 1$ \\
\hline Fumarate & $82 \cdot 3$ & $581^{a, b}$ & 0.85 & 1512 & $783^{a, b}$ & 261 & $2659^{a}$ & $93 \cdot 1$ \\
\hline 2-Oxoglutarate & 83.4 & 593 & 0.00 & $1777^{\mathrm{a}, \mathrm{b}}$ & $596^{\mathrm{b}}$ & 276 & $2775^{a}$ & $80 \cdot 4$ \\
\hline Malate & $90 \cdot 9^{a}$ & 594 & 0.21 & 1456 & $750^{a, b}$ & 244 & $2553^{b}$ & $98 \cdot 8$ \\
\hline Oxaloacetic acid & $97 \cdot 0^{\mathrm{a}}$ & 608 & $1 \cdot 18$ & $1582^{a}$ & $589^{b}$ & 282 & $2535^{\mathrm{b}}$ & $87 \cdot 4$ \\
\hline Propionate & $88 \cdot 2$ & 634 & 0.87 & 1485 & $950^{a}$ & 278 & $2818^{a}$ & $101 \cdot 0$ \\
\hline SED & $3 \cdot 18$ & $16 \cdot 5$ & 0.442 & $56 \cdot 8$ & $24 \cdot 2$ & $14 \cdot 1$ & $87 \cdot 2$ & \\
\hline
\end{tabular}

VFA, volatile fatty acids.

${ }^{\mathrm{a}, \mathrm{b}}$ Treatment was significantly $(P<0.05)$ different from control and propionate treatments, respectively. 
Table 5. The effects of adding propionate precursors on in vitro fermentation with a high-concentrate diet

\begin{tabular}{|c|c|c|c|c|c|c|c|c|}
\hline & $\begin{array}{l}\text { Gas } \\
(\mathrm{ml} / \mathrm{d})\end{array}$ & $\begin{array}{c}\mathrm{CH}_{4} \\
(\mu \mathrm{mol} / \mathrm{d})\end{array}$ & $\begin{array}{c}\mathrm{H}_{2} \\
(\mu \mathrm{mol} / \mathrm{d})\end{array}$ & $\begin{array}{l}\text { Acetate } \\
(\mu \mathrm{mol} / \mathrm{d})\end{array}$ & $\begin{array}{c}\text { Propionate } \\
(\mu \mathrm{mol} / \mathrm{d})\end{array}$ & $\begin{array}{l}\text { Butyrate } \\
(\mu \mathrm{mol} / \mathrm{d})\end{array}$ & $\begin{array}{c}\text { VFA } \\
(\mu \mathrm{mol} / \mathrm{d})\end{array}$ & $\begin{array}{c}\mathrm{H}_{2} \text { recovery } \\
(\%)\end{array}$ \\
\hline No addition & $98 \cdot 7$ & 641 & 0.61 & 1597 & 660 & 392 & 2772 & $88 \cdot 0$ \\
\hline Acrylate & $96 \cdot 9^{a}$ & $596^{a, b}$ & 0.83 & $1735^{a}$ & $833^{a, b}$ & 362 & $3037^{\mathrm{a}}$ & $84 \cdot 7$ \\
\hline Aspartate & $92 \cdot 1^{a, b}$ & 604 & $2 \cdot 13$ & 1530 & $783^{a, b}$ & $319^{a, b}$ & $2746^{b}$ & $92 \cdot 7$ \\
\hline Fumarate & $98 \cdot 1^{\mathrm{b}}$ & $582^{a, b}$ & 0.87 & 1696 & $938^{a, b}$ & 376 & $3133^{a}$ & $86 \cdot 6$ \\
\hline 2-Oxoglutarate & $96 \cdot 8^{\mathrm{b}}$ & 609 & 0.19 & $1850^{\mathrm{a}, \mathrm{b}}$ & $735^{\mathrm{b}}$ & 358 & $3083^{a}$ & $81 \cdot 2$ \\
\hline Malate & 101.4 & 621 & 1.55 & 1654 & $861^{a, b}$ & 378 & 3022 & $89 \cdot 3$ \\
\hline Oxaloacetic acid & $118 \cdot 3^{\mathrm{a}, \mathrm{b}}$ & 622 & 0.67 & $1781^{a}$ & $733^{\mathrm{b}}$ & 390 & 3017 & $82 \cdot 7$ \\
\hline Propionate & $105 \cdot 8^{a}$ & 650 & 1.32 & 1607 & $1118^{a}$ & 385 & $3232^{a}$ & $96 \cdot 9$ \\
\hline SED & $2 \cdot 60$ & $17 \cdot 5$ & 0.793 & $64 \cdot 1$ & $37 \cdot 2$ & $20 \cdot 9$ & $111 \cdot 1$ & \\
\hline
\end{tabular}

VFA, volatile fatty acids.

${ }^{\mathrm{a}, \mathrm{b}}$ Treatment was significantly $(P<0.05)$ different from control and propionate treatments, respectively.

Table 6. Influence of acrylate and fumarate addition $(6.25 \mathrm{mmol} / \mathrm{d})$ on $\mathrm{pH}$ and the production of volatile fatty acids (VFA), ammonia and gases $(\mathrm{mmol} / \mathrm{d})$ in the rumen simulating fermentor (Rusitec)

\begin{tabular}{|c|c|c|c|c|c|}
\hline & Control & Acrylate & Fumarate & SED & $P$ value \\
\hline $\mathrm{pH}$ & $6 \cdot 71^{b}$ & $6 \cdot 71^{b}$ & $6 \cdot 78^{a}$ & 0.026 & 0.0314 \\
\hline $\mathrm{H}_{2}$ & 0.34 & 0.26 & 0.27 & 0.103 & 0.6900 \\
\hline $\mathrm{CH}_{4}$ & $2 \cdot 46^{\mathrm{a}}$ & $2 \cdot 12^{a, b}$ & $1.78^{\mathrm{b}}$ & 0.208 & 0.0287 \\
\hline Acetate & $16 \cdot 3$ & $17 \cdot 3$ & $17 \cdot 9$ & 0.952 & 0.2673 \\
\hline Propionate & $7 \cdot 6^{\mathrm{b}}$ & $9 \cdot 7^{\mathrm{a}}$ & $10 \cdot 4^{a}$ & 0.560 & 0.0020 \\
\hline Iso-butyrate & 0.23 & 0.21 & 0.26 & 0.021 & 0.1190 \\
\hline Butyrate & $8 \cdot 1$ & 8.6 & 9.6 & 1.091 & 0.4473 \\
\hline Iso-valerate & $1 \cdot 71^{\mathrm{a}}$ & $0.41^{b}$ & $1.90^{\mathrm{a}}$ & 0.232 & 0.0002 \\
\hline Valerate & $5 \cdot 8$ & $6 \cdot 1$ & 6.9 & 0.537 & 0.1105 \\
\hline Total VFA & $39 \cdot 7^{\mathrm{b}}$ & $42 \cdot 4^{a, b}$ & $47 \cdot 1^{\mathrm{a}}$ & 2.914 & 0.0867 \\
\hline Acetate:propionate & $2 \cdot 14^{\mathrm{a}}$ & $1.79^{b}$ & $1.73^{b}$ & 0.067 & 0.0004 \\
\hline Ammonia & 58.0 & $60 \cdot 0$ & $62 \cdot 2$ & $5 \cdot 290$ & 0.7350 \\
\hline
\end{tabular}

${ }^{\mathrm{a}, \mathrm{b}}$ Values in a row not sharing a common superscript letters were significantly different, $P<0.05$.

production. The only other substantial change was that the production of iso-valerate was decreased compared with the control when acrylate was added. Fumarate, but not acrylate, increased $\mathrm{pH}$ within the Rusitec, but in all cases the $\mathrm{pH}$ was relatively stable at near neutral $(6 \cdot 71-6 \cdot 78)$.

The addition of acrylate or fumarate did not affect microbial numbers (Table 7). There was a non-significant $(P=0 \cdot 18)$ increase in DM digestion after $24 \mathrm{~h}$ fermentation in vessels supplemented with fumarate (Table 7).

\section{Discussion}

Many chemical compounds, such as ionophores, halogenated $\mathrm{CH}_{4}$ analogues and unsaturated fatty acids (Van Nevel \& Demeyer,
1996; Demeyer \& Fievez, 2000), anthraquinones (Kung et al. 2003), sulphur-containing amino acids (Takahashi, 2001), inhibitors of methanogenic archaea (Miller \& Wolin, 2001) and inhibitors of oxidative pyruvate decarboxylation (Ungerfeld et al. $2003 b$ ) have been studied as potential feed additives to suppress $\mathrm{CH}_{4}$ production in the rumen (Moss et al. 2000). Some of these compounds inhibit the growth of $\mathrm{CH}_{4}$-producing archaea, whereas others have an effect on the metabolic pathways involved in producing $\mathrm{H}_{2}$ as a substrate for methanogenesis.

Although some chemicals may be capable of decreasing ruminal $\mathrm{CH}_{4}$ production, there is growing concern over the use of chemicals not normally associated with human foods in farm animals. As methanogenesis is principally a sink for metabolic $\mathrm{H}_{2}$ in the rumen, a possible alternative is the use of compounds,

Table 7. Influence of acrylate and fumarate addition $(6.25 \mathrm{mmol} / \mathrm{d})$ on microbial numbers and DM digestion in the rumen simulating fermentor (Rusitec)

\begin{tabular}{lccccc}
\hline & Control & Acrylate & Fumarate & SED & $P$ value \\
\hline Total viable bacteria $\left(\times 10^{8} / \mathrm{ml}\right)$ & 5.53 & 5.06 & 4.90 & 1.388 & 0.8977 \\
Cellulolytic bacteria $\left(\times 10^{6} / \mathrm{ml}\right)$ & 4.26 & 5.50 & 8.51 & 2.641 & 0.3020 \\
Protozoa $\left(\times 10^{3} / \mathrm{ml}\right)$ & 0.73 & 0.90 & 0.67 & 0.316 & 0.7621 \\
DM $(\mathrm{g})$ digested after $24 \mathrm{~h}$ & 2.80 & 3.00 & 3.75 & 0.485 & 0.1754 \\
DM digestibility after $24 \mathrm{~h}(\mathrm{~g} / \mathrm{kg})$ & 166 & 176 & 217 & 28.0 & 0.2150 \\
DM $(\mathrm{g})$ digested after $48 \mathrm{~h}$ & 6.34 & 6.22 & 6.98 & 0.709 & 0.5419 \\
DM digestibility after 48 $\mathrm{h}(\mathrm{g} / \mathrm{kg})$ & 383 & 365 & 402 & 41.7 & 0.6803 \\
\hline
\end{tabular}


such as propionate or butyrate precursors (Asanuma et al. 1999; López et al. 1999b; Ungerfeld et al. 2003a), that may act as electron sinks competing with methanogens for the available $\mathrm{H}_{2}$. Dicarboxylic acids, including aspartate, malate and fumarate, which may act as $\mathrm{H}_{2}$ acceptors in the rumen, have been tested (Callaway \& Martin, 1996; Martin \& Park, 1996). These organic acids or their metabolites are reduced by ruminal bacterial species that use either $\mathrm{H}_{2}$ or formate as electron donors (Asanuma et al. 1999). The rumen microflora has a high capacity to reduce fumarate (Asanuma \& Hino, 2000), and although the fumarateutilizing bacteria have a lower affinity for $\mathrm{H}_{2}$ or formate than methanogens (Asanuma et al. 1999), the reduction of fumarate may to some extent compete with methanogenesis for the metabolic $\mathrm{H}_{2}$, such that in the presence of this acid, $\mathrm{CH}_{4}$ production can be decreased (Asanuma \& Hino, 2000). The results presented here extend these observations to describe the short- and longer-term effects of a number of propionate precursors on $\mathrm{CH}_{4}$ production. Possible fermentation pathways in the rumen of the compounds used are shown in Fig. 1. All are potential precursors of propionate.

The molar conversion of organic acids to propionate in batch cultures varied between zero for tartrate and $68 \%$ for fumarate. This compares well with previous studies in which the percentage transfer of fumarate to propionate varied between 40 and $85 \%$ (Callaway \& Martin, 1996; López et al. 1999b; Carro \& Ranilla, 2003b). Carro \& Ranilla (2003a), studying the fermentation of cereal grains, suggested that diet might influence the efficiency with which organic acids are converted to propionate; however, no consistent effect of diet was found in the present study, with 52, 58 and $50 \%$ of acrylate, fumarate and malate being converted to propionate in fermentations with a forage diet, and 43, 69 and $50 \%$, respectively, being converted with a concentrate diet.

Although a number of compounds were found to decrease $\mathrm{CH}_{4}$ production, the most consistent decreases in $\mathrm{CH}_{4}$ production and increases in propionate production were found with fumarate and acrylate. Demeyer \& Henderickx (1967) observed that the addition of $500 \mu \mathrm{M}$ fumarate inhibited in vitro $\mathrm{CH}_{4}$ production by $60 \%$. The largest decrease noted in the present study was a $17 \%$ decrease in $\mathrm{CH}_{4}$ production in response to the addition of $400 \mu \mathrm{M}$ fumaric acid. This decrease is consistent with the decreases in $\mathrm{CH}_{4}$ observed in vitro when fumarate was included in the incubations of Callaway \& Martin (1996) and Carro \& Ranilla (2003b) (15 and 5\%, respectively). Ungerfeld et al. (2003a) previously reported a variable decrease in $\mathrm{CH}_{4}$ production when some propionate and butyrate enhancers and analogues were evaluated in vitro.

Based on the equation $4 \mathrm{H}_{2}+\mathrm{CO}_{2}=\mathrm{CH}_{4}+2 \mathrm{H}_{2} \mathrm{O}$, and the reduction of fumarate to succinate or acrylate to propionate by $2 \mathrm{H}$ (Fig. 1), the efficiency of $\mathrm{H}_{2}$ capture by fumarate was on average $70 \%$ in batch cultures, whereas the figures for acrylate were nearer $100 \%$. Thus, despite the more efficient conversion of fumarate to propionate in comparison with the conversion of acrylate to propionate, both caused on average a $10 \%$ decrease in $\mathrm{CH}_{4}$ production over all the in vitro batch incubations. A greater response occurred with free fumarate and malate compared with sodium salts. Although the addition of free acids was associated with a decrease in the $\mathrm{pH}$ of the cultures, the change was very small and the resultant $\mathrm{pH}$ remained in the range optimal for $\mathrm{CH}_{4}$ formation (Russell, 1998). Unless solubility or rate of dissolution was affected, it is unclear why the free acids were more effective.
Additives used to decrease $\mathrm{CH}_{4}$ production in ruminal fermentations have had a variable effect depending on the substrate used as feed for the fermentation (García-López et al. 1996). Thus, a subset of the most promising compounds was examined with two diets of different forage:concentrate ratio added to the in vitro incubations. Again, the greatest response, in terms of a reduction in $\mathrm{CH}_{4}$, was observed with fumarate and acrylate, with little difference between both diets in terms of the effect of the acids on $\mathrm{CH}_{4}$ production (decreases of 8 and $6 \%$ with a forage diet, and of 7 and $9 \%$ with a concentrate diet when adding either acrylate or fumarate, respectively).

Stoichiometrically, the decrease in $\mathrm{CH}_{4}$ production accounted for 68 and $85 \%$ of the $\mathrm{H}_{2}$ used to convert fumarate into propionate when forage or concentrate diets were fermented, respectively, although no differences were detected between diets in total $\mathrm{H}_{2}$ recovery (93 and $87 \%$ for the forage and concentrate diet, respectively).

Acrylate and fumarate were further evaluated in Rusitec. Of the added acrylate and fumarate, 33 and $44 \%$ respectively was recovered in propionate. However, fumarate appeared more efficient in decreasing $\mathrm{CH}_{4}$ production ( 28 v. $14 \%$ decrease), and this effect was consistent over the period of time the Rusitec experiment lasted, in agreement with the results of López et al. (1999b), who also found that the effect of fumarate on $\mathrm{CH}_{4}$ production in semi-continuous cultures persisted. The decrease of $0.68 \mathrm{mmol} / \mathrm{d}$ in $\mathrm{CH}_{4}$ production with sodium fumarate corresponds to a utilization of $4 \times 0.68=2.72 \mathrm{mmol} \mathrm{H} \mathrm{H}_{2} / \mathrm{d}$, close to the $2.8 \mathrm{mmol} / \mathrm{d}$ increase in propionate production, suggesting an efficient capture of $\mathrm{H}_{2}$ with fumarate. With sodium acrylate, the decrease in $\mathrm{CH}_{4}$ production was $0.34 \mathrm{mmol} / \mathrm{d}$, equivalent to the diversion of $1.36 \mathrm{mmol} \mathrm{H}_{2} /$ d. Propionate production increased by $2.1 \mathrm{mmol} /$ $\mathrm{d}$, indicating that $\mathrm{H}_{2}$ capture by acrylate was less efficient than by fumarate.

Other beneficial effects of adding propionate precursors may occur, for reasons that may not be related to methanogenesis. Apparent DM degradation was increased in batch cultures by between 10 and $16 \%$ by the addition of fumarate, 2-oxoglutarate, malate and tartrate. Increases in DM degradation were not observed when free acids were used. Ungerfeld et al. (2003a) observed that some propionate and butyrate precursors or analogues increased apparent substrate fermentation in vitro. Carro and Ranilla (2003b) observed a small increase (approximately $4 \%$ ) in the apparent in vitro digestibility of maize supplemented with fumarate. Fumarate also increased numerically the apparent DM degradation in Rusitec (Table 7).

The ability of dicarboxylic acids to stimulate ruminal fermentation may be associated with differences in $\mathrm{pH}$, although these may be small, and to the removal of $\mathrm{H}_{2}$. In the current study, no consistent effect of the additives used on $\mathrm{pH}$ in batch cultures were observed, possibly owing to the inherent buffering capacity of the incubation medium used. In Rusitec, fumarate but not acrylate caused an increase in $\mathrm{pH}$; again, the response was small, probably reflecting the buffering capacity of the medium used. The addition of fumarate might be associated with higher $\mathrm{pH}$ values, in part because these dicarboxylic acids stimulate lactate uptake and utilization by some bacterial species (Martin, 1998). It is noteworthy that $\mathrm{CH}_{4}$ production is decreased with the addition of fumarate, even though an increased $\mathrm{CH}_{4}$ production may be expected in response to a higher ruminal $\mathrm{pH}$ (Russell, 1998). 
In addition, it has been shown that cellulolytic organisms benefit from the presence of methanogenic or other $\mathrm{H}_{2}$-utilizing bacteria as a result of interspecies $\mathrm{H}_{2}$ transfer (Wolin et al. 1997). Thus, if $\mathrm{H}_{2}$ removal were increased by the presence of propionate precursors, this might also stimulate the growth of fibrolytic bacteria (López et al. 1999b) and enhance cellulose digestion (Asanuma \& Hino, 2000).

It is thus apparent that organic acids might be used to decrease ruminal methanogenesis in farm livestock. In steers, $\mathrm{CH}_{4}$ production from the rumen was reduced by $23 \%$ by fumaric acid supplementation $(20 \mathrm{~g} / \mathrm{kg})$ without affecting the digestibility of the dietary fibre (Bayaru et al. 2001). The results of the present study suggest that we might expect to see approximately $50 \%$ of the fumarate being used to divert $\mathrm{H}_{2}$ from $\mathrm{CH}_{4}$ formation, mainly owing to the conversion of fumarate into products other than propionate. Thus, in order to decrease $\mathrm{CH}_{4}$ production by 1 litre (1/ $22.4=0.045 \mathrm{~mol}$, assuming that $1 \mathrm{~mol}$ gas $=22.4$ litre), one would require $4 \times 0.045 \mathrm{~mol}$ fumarate at $100 \%$ efficiency, or $2 \times 4 \times 0.045=0.36 \mathrm{~mol}$ sodium fumarate at $50 \%$ efficiency. The $M_{\mathrm{r}}$ of disodium fumarate is 160 , so $0.36 \times 160=58 \mathrm{~g}$ disodium fumarate would be required for a 1 litre decrease in $\mathrm{CH}_{4}$ formation. In a dairy cow producing 500 litres $\mathrm{CH}_{4} / \mathrm{d}$, a decrease in $\mathrm{CH}_{4}$ of just $10 \%$ would require $2.9 \mathrm{~kg}$ sodium fumarate (or $2.1 \mathrm{~kg}$ fumaric acid) to be fed. The implications of feeding these quantities of fumarate need to be considered.

The fumarate necessary for a $10 \%$, or 50 litre, decrease in $\mathrm{CH}_{4}$ formation would produce $50 \times 0 \cdot 18=9 \mathrm{~mol}$ propionate. One might argue that such an increase in propionate production would lead to an increase in glucose synthesis and hence in milk lactose: assuming a $70 \%$ efficiency in the conversion of propionate to glucose and a $40 \%$ conversion of glucose to lactose (Baldwin \& Kim, 1993), the fumarate could lead to benefits in terms of $200 \mathrm{~g}$ additional lactose or 4.5 litres liquid milk at a lactose concentration of $4.8 \%$. Furthermore, as already noted, there may be other benefits from fumarate addition. Martin et al. (1999) found that malate increased average daily gain in cattle fed a high-concentrate diet, apparently by improving ruminal function.

There is also the practicality of feeding such substantial amounts of fumarate. Feeding the free acid may be problematic because of concerns over rumen $\mathrm{pH}$. However, as a salt, $2 \mathrm{~kg}$ disodium fumarate would provide $550 \mathrm{~g} \mathrm{Na}$, which is well in excess of all current recommendations and may indeed induce toxicity (National Research Council, 2001). Similarly excess propionate in the rumen may lead to a decrease in feed intake and problems such as reduced milk fat content in dairy cows and soft fat in lambs (Ørskov \& Ryle, 1990; Oba \& Allen, 2003). Thus, although organic acids such as fumarate may be of interest as a means of decreasing $\mathrm{CH}_{4}$, thought needs to be given to the economics of the approach and the mechanism of supply.

A further consideration is that the effects of certain propionate and butyrate enhancers would be expected to be additive. 2Oxoglutarate was almost as effective as sodium acrylate in decreasing $\mathrm{CH}_{4}$ formation. In all incubations except those with the highconcentrate diet, 2-oxoglutarate did not form as much propionate as some other salts, but it formed butyrate as well as propionate. This result may indicate that combining certain compounds, forming more than one $\mathrm{H}_{2}$ sink, may have a cumulative effect. For example, adding fumarate alone diverts $\mathrm{H}_{2}$ into the dicarboxylic acid pathway for propionate formation. Adding acrylate as well could increase propionate production even more because it feeds into a different mechanism for propionate formation, the acrylate pathway, which occurs in organisms different from those using the dicarboxylic acid pathway. Adding a butyrate enhancer could utilize further reducing equivalents. Thus, the apparent limit of a $10 \%$ decrease in $\mathrm{CH}_{4}$ formation for single $\mathrm{H}_{2}$-sink compounds may be modest in comparison with what might be achieved by combining electron-sink feed additives.

In conclusion, although it might be possible to use organic acids, and fumarate in particular, to decrease ruminal $\mathrm{CH}_{4}$ production, the quantities required to make a major impact on daily $\mathrm{CH}_{4}$ production might well be impractical.

\section{Acknowledgements}

This work was supported by the Ministry of Agriculture, Food and Fisheries, UK, and the Scottish Executive Environment and Rural Affairs Department. J.O.O. is grateful to the Kenya Agricultural Research Institute for his scholarship. C.J.N. and S.L. acknowledge joint funding by the Spanish Ministerio de Educación y Ciencia and the British Council under Accion Integrada HB1996-0150.

\section{References}

Asanuma N \& Hino T (2000) Activity and properties of fumarate reductase in ruminal bacteria. J Gen Appl Microbiol 46, 119-125.

Asanuma N, Iwamoto M \& Hino T (1999) Effect of the addition of fumarate on methane production by ruminal microorganisms in vitro. J Dairy Sci 82, 780-787.

Baldwin RL \& Kim WY (1993) Lactation. In Quantitative Aspects of Ruminant Digestion and Metabolism, pp. 433-451 [JM Forbes and J France, editors]. Wallingford, UK: CAB International.

Bayaru E, Kanda S, Kamada T, et al. (2001) Effect of fumaric acid on methane production, rumen fermentation and digestibility of cattle fed roughage alone. Anim Sci J 72, 139-146.

Bryant MP (1972) Commentary on the Hungate technique for culture of anaerobic bacteria. Am J Clin Nutr 25, 1324-1328.

Callaway TR \& Martin SA (1996) Effects of organic acid and monensin treatment on in vitro mixed ruminal micro-organisms fermentation of cracked corn. J Anim Sci 74, 1982-1989.

Carro MD \& Ranilla MJ (2003a) Effect of the addition of malate on in vitro rumen fermentation of cereal grains. Br J Nutr 89, 181-188.

Carro MD \& Ranilla MJ (2003b) Influence of different concentrations of disodium fumarate on methane production and fermentation of concentrate feeds by rumen micro-organisms in vitro. Br J Nutr 90, 617-623.

Czerkawski JW \& Breckenridge G (1977) Design and development of a long term rumen simulation technique (Rusitec). Br J Nutr 38, 371-384.

Demeyer D \& Fievez V (2000) Ruminants and environment: methanogenesis. Ann Zootech 49, 95-112.

Demeyer DI \& Henderickx HK (1967) Competitive inhibition of in vitro methane production by mixed rumen bacteria. Arch Int Physiol Biochim 75, 157-159.

Demeyer DI \& Van Nevel CJ (1975) Methanogenesis, an integrated part of carbohydrate fermentation and its control. In Digestion and Metabolism in the Ruminant, pp. 366-382 [IW McDonald and ACI Warner, editors]. Armidale, Australia: University of New England Publishing Unit.

García-López PM, Kung L \& Odom JM (1996) In vitro inhibition of microbial methane production by 9,10-anthraquinone. J Anim Sci 74, 2276-2284.

Goering HK \& Van Soest PJ (1970) Forage Fiber Analyses (Apparatus, Reagents, Procedures and Some Applications). USDA Handbook No. 379. Washington DC: USDA. 
Hobson PN (1969) Rumen bacteria. Methods Microbiol, 3B, 133-159.

Hungate RE (1969) A roll tube method for cultivation of strict anaerobes. Methods Microbiol 3B, 117-132.

Jalc D \& Ceresnakova Z (2002) Effect of plant oils and malate on rumen fermentation in vitro. Czech J Anim Sci 47, 106-111.

Kung L Jr, Smith KA, Smagala AM, Endres KM, Bessett CA, Ranjit NK \& Yaissle J (2003) Effects of 9,10 anthraquinone on ruminal fermentation, total-tract digestion, and blood metabolite concentrations in sheep. J Anim Sci 81, 323-328.

López S, McIntosh FM, Wallace RJ \& Newbold CJ (1999a) Effect of adding acetogenic bacteria on methane production by mixed rumen microorganisms. Anim Feed Sci Technol 78, 1-9.

López S, Valdes C, Newbold CJ \& Wallace RJ (1999b) Influence of sodium fumarate on rumen fermentation in vitro. Br J Nutr 81, 59-64.

McDougall EI (1948) Studies on ruminal saliva 1. The composition and output of sheep's saliva. Biochem J 43, 99-109.

Mann SO (1968) An improved method for determining cellulolytic activity in anaerobic bacteria. J Appl Bacteriol 31, 241-244.

Martin SA (1998) Manipulation of ruminal fermentation with organic acids: a review. J Anim Sci 76, 3123-3132.

Martin SA \& Park CM (1996) Effect of extracellular hydrogen on organic acid utilization by the ruminal bacterium Selenomonas ruminantium. Curr Microbiol 32, 327-331.

Martin SA, Streeter MN, Nisbet DJ, Hill GM \& Williams SE (1999) Effects of DL-malate on ruminal metabolism and performance of cattle fed a high-concentrate diet. J Anim Sci 77, 1008-1015.

Miller TL \& Wolin MJ (2001) Inhibition of growth of methane-producing bacteria of the ruminant forestomach by hydroxymethylglutaryl-SCoA reductase inhibitors. J Dairy Sci 84, 1445-1448.

Moss AR (1993) Methane Global Warming and Production by Animals. Canterbury: Chalcombe Publications.

Moss AR, Jouany JP \& Newbold CJ (2000) Methane production by ruminants: its contribution to global warming. Ann Zootech 49, $231-253$.

National Research Council (2001) Nutrient Requirements of Dairy Cattle, 7th revised ed. Washington DC: National Academy Press.
Newbold CJ, Lassalas B \& Jouany JP (1995) The importance of methanogens associated with ciliate protozoa in ruminal methane production in vitro. Lett Appl Microbiol 21, 230-234.

Newbold CJ, Wallace RJ \& McIntosh FM (1997) Mode of action of the yeast Saccharomyces cerevisiae as a feed additive for ruminants. $\mathrm{Br}$ J Nutr 76, 249-261.

Newbold CJ, Williams AG \& Chamberlain DG (1987) The in vitro metabolism of D,L-lactic acid by rumen microorganisms. J Sci Food Agric 38, 9-19.

Oba M \& Allen MS (2003) Extent of hypophagia caused by propionate infusion is related to plasma glucose concentration in lactating dairy cows. J Nutr 133, 1105-1112.

Ørskov ER \& Ryle M (1990) Energy Metabolism in Ruminants. London: Elsevier Science.

Russell JB (1998) The importance of $\mathrm{pH}$ in the regulation of ruminal acetate to propionate ratio and methane production in vitro. J Dairy Sci $\mathbf{8 1}$, 3222-3230.

Steel RGD \& Torrie JH (1980) Principles and Procedures of Statistics. New York: McGraw-Hill.

Stewart CS \& Duncan SH (1985) The effect of avoparcin on cellulolytic bacteria of the ovine rumen. J Gen Microbiol 131, 427-435.

Takahashi J (2001) Nutritional manipulation of methanogenesis in ruminants. Asian-Australasian J Anim Sci 14, 131-135.

Ungerfeld EM, Rust SR \& Burnett R (2003a) Use of some novel alternative electron sinks to inhibit ruminal methanogenesis. Reprod Nutr Dev 43, 189-202.

Ungerfeld EM, Rust SR \& Burnett R (2003b) Attempts to inhibit ruminal methanogenesis by blocking pyruvate oxidative decarboxylation. Can J Microbiol 49, 650-654.

Van Nevel CJ \& Demeyer DI (1996) Control of rumen methanogenesis. Environ Monit Assess 42, 73-97.

Weatherburn MW (1967) Phenol-hypochlorite reaction for determination of ammonia. Anal Chem 39, 971-974.

Wolin MJ, Miller TL \& Stewart CS (1997) Microbe-microbe interactions. In The Rumen Microbial Ecosystem, 2nd edition, pp. 467-491 [PN Hobson and CS Stewart, editors]. London: Blackie Academic \& Professional. 